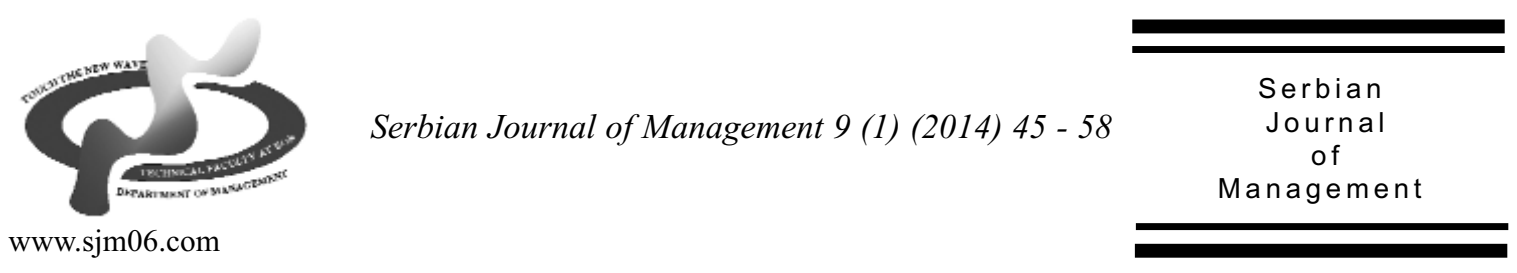

\title{
PERFORMANCE MANAGEMENT IN INTERNATIONAL HUMAN RESOURCE MANAGEMENT: EVIDENCE FROM THE CEE REGION
}

\author{
Agneš Slavić, Nemanja Berber* and Bojan Leković \\ University of Novi Sad, Faculty of Economics in Subotica, Department of Management, \\ Novi Sad, Serbia
}

(Received 16 October 2013; accepted 2 January 2014)

\begin{abstract}
Performance management (PM) is a very important process of human resource management (HRM), in general. It implies an assessment of current or previous results or performance of the employee, team or the whole organization. It is a base for many business practices related to HRM: the need for staff training, new recruitment, career development, rewarding, etc. A wide literature sources emphasized that PM is a complex process, especially when the global market is in the scope of the research. This paper examined the performance management from the aspect of international human resource management (IHRM). The main objective of this paper was to explore the area of performance management in context of IHRM and relations between the existence of formal appraisal systems (FAS) for performance management and organizational performances. The research was carried out trough literature and empirical research based on CRANET data base. Methodology used in the research included statistical techniques of descriptive statistics and independent t-test, performed with SPSS program. Authors explored data from organizations from 7 countries from the Central and Eastern Europe (CEE) region.
\end{abstract}

Keywords: performance management, international human resource management, formal appraisal system, manager, Central and Eastern Europe

\section{INTRODUCTION}

A great number of empirical studies show that HRM has positive relationship on firm performance and also can be the source of sustainable competitive advantage to the organization (Beh \& Loo, 2013). In the research of the HRM, in relation to the understanding of the people as a factor that contributes to the competitiveness of the

\footnotetext{
* Corresponding author: berber@ef.uns.ac.rs

DOI: 10.5937/sjm9-4678
} 
organization, inevitably raises the question of the functioning of this process in the context of the globalization, which is defined as the process of increasing interconnectedness of individuals, groups, companies and countries. The technological, economic and political changes which have brought people closer together have also generated serious concerns over the terms of that integration (Mura, 2012).

If we look at global markets and multinational companies, and analyze human resource management at the international level, we can note the increasing complexity of the human resource management. The domestic human resource management situation is somewhat simpler and easier for manager structure because the business is done on a particular territory, inside specific national culture and business environment. By entering on the global business environment, the company comes into contact with a number of challenges, such as meeting new national cultures, uncertainty due to the entry on the new and unknown markets, meeting other legal regulations related to labor relations, the influence of new knowledge, technologies and forms of work, and the like. Therefore, human resources management has to become increasingly important in the functioning of national and international organizations (Poor et al., 2012).

This paper examined the performance management from the aspect of IHRM. Namely, performance management (PM) is a very important process of human resource management (HRM), in general. It implies an assessment of current or previous results or performance of the employee, team or the whole organization. On such assessments companies creates its policies in many business areas related to HRM: the need for staff training, new recruitment, career development, rewarding, etc. Performance measurement is an assessment of current or previous results of the performance of the employee. Performance evaluation approach can be two fold - individual level and on exact data. First approach involves contact by type "face to face"; it is difficult for assessors because it activates emotions that can easily lead to conflict. Another approach focuses on the working process that is based on the exact data - results of the quantification and comparison with the standards (Štangl-Šušnjar \& Zimanji, 2005). PM in HRM can be made by different management methods such as management by objectives, multilaterally evaluation, bars, the method of critical events, ranking, essays, etc.

In the line with the general orientation of the paper, the main objective of this paper was to explore the area of performance management in context of IHRM and relations between the existence of formal performance measurement systems and organizational performances. The research was carried out trough deep literature research and empirical research based on CRANET data base. Methodology used in the research included statistical techniques of descriptive statistics and independent t-test, performed with SPSS program. Authors explored data from organizations which operate in 7 countries from Central-Eastern Europe region: Estonia, Czech Republic, Slovakia, Slovenia, Bulgaria, Hungary and Serbia.

\section{THEORETICAL BACKGROUND}

According to Neely, Gregory and Plats (1995) performance measurement is defined 
as the process of quantifying effectiveness and efficiency of actions. One comprehensive definition of performance measurement is that PM is the process of quantifying the efficiency and effectiveness of actions, in order to compare results against expectations, with the intent to motivate, guide and improve decision making (Lardenoije et al., 2005). The performance measures should be relevant, balanced, based on financial and non-financial indicators and related to internal and external stakeholders. Measures need to be related directly to the organization's mission and objectives in order to reflect the company's external competitive environment, customer requirements and internal objectives (Kennerley \& Neely, 2002). Also, PM is seen as an important element in the management of the compensation process (Berber et al., 2012).

In the context of IHRM it is necessary to emphasize that although the most expensive employees in each company are expatriates (Brewster \& Scullion, 1997; Lee \& Liu, 2006), yet there is a poor knowledge about measuring their performance and contributions to the organizations. Of course, a complex system for performance management of expatriates was developed. But, these systems are not universal, so it is necessary to know and understand the specific variables that affect the success or failure of an expatriate in the foreign country (Brewster et al., 2007). The international system of employees' performance management is a designed and implemented intervention by the MNCs with the goal of the management of the performances of the global workforce (individual, team and organizational performances) so that those performances contribute to the achievement of the global strategic objectives and results of MNCs (Briscoe et al., 2009). The global performance management system is based on corporate values and goals, tailored to the different countries, depending on cultural sensitivity and knowledge of the process of the direct feedback (Engle et al., 2008; Festing \& Eidems, 2011).

In their recent study the authors Festing, Knappert, Dowling and Engle, through the discussion of the performance management, identified five main characteristics of the performance management of employees that structure the conceptual and empirical discourses in the research: individual objectives or performance evaluation criteria, actors' role during the appraisal, applied methods, interventions and purposes of the system, the way of the provided feedback (Festing et al., 2012). The usage of the mentioned performance management system requires both, global standardization and local responsiveness. Namely, in describing and testing the necessary balance between standardization and localization, Vance distinguishes two main parts of the performance management process: strategic upstream processes coordinated by the headquarters and the downstream processes that are more adapted to local requirements. While upstream considerations are characterized by coordination, knowledge management, and organizational learning, downstream activities include sensitivity to cross-cultural differences such as the choice between individuals versus groups as rates during the assessment (Vance, 2006). Evans, Pucik and Björkman stated that although multinational companies need to have a global template for assessment procedures, they must allow the local business units of a certain level of freedom to customize the template to local conditions (Evans et al., 2011). 
Organizations develop performance management systems for different reasons, but primarily goals of these systems are related to the evaluation and development (Cascio, 2006). Evaluation goals for global PMS in the international environment include:

- providing feedback to employees at all levels so they will know where they stand;

- developing valid bases for employment decisions involving pay, promotions, job assignments, retention and termination decisions; and

- providing a means to warn employees about unsatisfactory performance.

Development goals for global performance management systems in the IHRM include:

- helping employees at all levels to improve their performance and develop their professional skills;

- diagnosing individual and organizational problems;

- enhancing commitment to the organization through discussions of career opportunities, action plans and needs for training and development; and

- using recognition to motivate continued or improved high performance (Cascio, 2006).

By bearing in mind the three main purposes of the global performance management (GPM):

- providing general feedback and decision consequences;

- contribution to the development of the contextual performances;

- creation and maintaining of the strong, dominant and integrative corporate culture

we have to consider the GPM as a process (Dowling et al., 2008). Cascio (2006) emphasize three most important elements of this process: define performances, facilitate performance (elimination of the barriers) and encourage performances.

Caligiuri presents a five step process:

- determine 'the broad content domain' of performance across countries for the same position;

- determine if these jobs are comparable;

- if so, create 'conceptual equivalence' that can be applied across cultures and countries;

- determine 'how' the evaluations will be organized and

- 'who' will conduct the appraisal(s) (Caligiuri, 2006).

In the line with the above mentioned concept of Caligiuri, we will continue with the explanation why it is so important to manage performances of the expatriates, who should do that task and the way it should be done.

Although it was stated that the information derived from the process of the performance management have an impact on development goals of employees and assist generally in the evaluation, it is necessary to take into account the aspect of costs of the expatriation, not only the international compensation, which is a very complex, but also some other direct and indirect costs that may be incurred due to the failure of expatriate, burnout during the international assignment, a high rate of leaving the organization during and after the repatriation process, as well as the low level of the recognition for overseas assignments and 
low formality in the process of measuring performance.

When we talk about subjects who should carry out the performance evaluation of the expatriates, the authors of the IHRM often emphasize several "reviewers" like peers, customers, sponsors, HR managers, supervisors, etc. Main raters of the expatriate's performances are presented in the table 1 .

The biggest controversy in the performance management is related to the level of management that should carry out this process: local or corporate manager. Managers at the corporate level in the home country are often not familiar with the details of the foreign assignment, and it is very difficult to implement this process in a distance that sometimes amounts to several thousand kilometers in a foreign country. Most often this process is carried out by a direct supervisor in the host country and home country supervisor. Beside them, in the assessment process of expatriates there have been included customers, suppliers, banks, etc. Corporate headquarters usually send employees to visit the expatriate in order to check the state of the foreign assignment. This type of the performance evaluation of expatriates is called the 360-degree evaluation process or multilaterally $\left(360^{\circ}\right.$ review process - evaluation system) (Godiwalla, 2012). It involves the assessment from the above, below, from the sides and self-evaluation and it is very complex, due to the above reasons.

When the way of performance measurement is in question, usually there is confusion about "what" and "when" should be measured. Criteria for the performance management from the point of view of the best-known authors in this field, such as Cascio (2006) and Woods, Barker and Trothsu (2012) are:

- objective (hard) criteria - return on investment (ROI), market share, total revenue, cost reduction, net income and budget. The performance measures are commonly focused on financial criteria, with few studies taking into consideration the broader issue of employee satisfaction, commitment, and well-being (Singh et al., 2012);

- $\quad$ subjective (soft) criteria - leadership style and interpersonal skills;

- contextual criteria - take into consideration factors that result from the situation in which performance occurs. They include organizational citizenship behaviors (helping and cooperating with others, working with enthusiasm, volunteering for activities, being flexible and open to change) as well as indicators of cross-cultural skill development (for example, language, host culture, communication, networking) (Cascio, 2006).

MNEs cannot simply use standard appraisal criteria - developed in the domestic

Table 1. Raters of the expatriates'performances

\begin{tabular}{|l|l|l|l|}
\hline Inside the host country & Outside the host country \\
\hline Customers & $1 \%$ & Sponsor & $7 \%$ \\
\hline Subordinates & $7 \%$ & HR professional from the corporate level & $17 \%$ \\
\hline Peers & $10 \%$ & Regional manager & $23 \%$ \\
\hline HR professionals & $12 \%$ & Supervisor & $41 \%$ \\
\hline Self-evaluation & $39 \%$ & & \\
\hline Supervisor & $75 \%$ & & \\
\hline
\end{tabular}

Source: Briscoe et al., 2009, p. 302. 
context - overseas and expect valid results. External factors usually influence the financial and operational results much more so in the overseas environment than they do domestically. Items like severe inflation, currency devaluations, local leave and holiday requirements, and thirteenth-month pay norms just are not issues in the domestic context for many MNEs (Cascio 2006). MNEs need to construct criteria for evaluation according to each subsidiary's unique situation in host country (Woods et al., 2012; Brewster, 1991), respecting politic, economic and culture system of the host country. Since there are several problems of measuring hard criteria because of the mentioned reasons, subjective (soft) and contextual criteria are added as the complements to the hard criteria.

Actually, these three forms of criteria can be explained by general polarization between financial and non financial indicators in performance management (SimonescuBratu, 2013). According them, any organization has to understand that it needs to give impetus not only towards the financial results but also towards satisfaction of the customers, development of state-ofthe-art technologies and creation of an environment of learning and growth. One of the solutions, well known in the area of performance management, is the balanced scorecard (Kaplan \& Norton, 1996), which has considered not just the financial indices but also the non-financial indicators as equally critical in determining organizational performance.

The end of the theoretical part of the study of performance management in international HRM refers to the frequency and period of performance measurement. A formal assessment is usually done on an annual basis, and this model is applied on an international level. However, for the USA region it is characteristically that companies that carry out the assessment on an annual base commonly use standardized forms and objective criteria in this process. Performance measurement of the expatriate once or twice a year is in positive correlation with accuracy of performance management and frequent measurements would also have a positive effect on this process (Gregersen et al., 1996).

\section{METHODOLOGY AND DATA}

CRANET methodology (www.cranet.org) has been used to identify the practice of the performance management in organizations from the CEE region. CRANET is the international organization which organizes comparative researches on the policies and practices of human resource management, using a standardized questionnaire. The purpose of the research is to provide high quality data for academics, public and private sector organizations, as well as HRM students, and to create new knowledge about human resource management practice in different countries of the world. In CRANET research period from 2008 until 2010 there were involved 32 countries, but for this analysis authors decided to explore only data for organizations from CEE region. Countries involved in the research were: Bulgaria, Czech Republic, Estonia, Hungary, Slovakia, Slovenia and Serbia. CRANET methodology and data were also used in research of on many other HR activities such as compensations and benefits (Štangl Šušnjar \& Slavić, 2012), HRM outsourcing (Susomrith \& Brown, 2013; Štangl Šušnjar et al., 2013), training and development (McNamara et al., 2012), the influence of the 
culture on HRM practices in MNCs (Papalexandris \& Panayotopoulou, 2004), etc. Methodology included the application of the program SPSS Version 21.

Sample of organizations used in the research is presented in table 2 . Total number of organizations from seven countries was 1028.

Sector distribution of the sample used in the research is presented in figure 1. Main part of the sample made private sector companies $(66.1 \%)$, then public $(17.7 \%)$ and not for profit $(11.5 \%)$.

Main goals of the research were:

- to find out whether organizations form the CEE region use formal performance management systems,

- to find out who are the most important „reviewers” of managers' performances,

- to explore the differences between organization which use formal appraisal systems and those that do not use them, in relation to the organizational performances.

The analysis was carried put trough three steps. First, it has been made a descriptive statistics using crosstabs to identify the level of the usage of formal appraisal systems (FAS) in performance management for the category of managers in observed organizations. Second, similar technique has been used to explore who is responsible for the appraisal of the managers' performances in these organizations. After that, the third part of the analysis obtained the independent t-test to investigate are there are differences

Table 2. Countries and number of organizations included in the research

\begin{tabular}{|l|c|c|c|}
\hline & Frequency & Percent & Cumulative Percent \\
\hline Bulgaria & 267 & 26,0 & 26,0 \\
\hline Czech Republic & 54 & 5,3 & 31,2 \\
\hline Estonia & 74 & 7,2 & 38,4 \\
\hline Hungary & 139 & 13,5 & 51,9 \\
\hline Slovakia & 225 & 21,9 & 73,8 \\
\hline Slovenia & 219 & 21,3 & 95,1 \\
\hline Serbia & $\mathbf{5 0}$ & $\mathbf{4 , 9}$ & $\mathbf{1 0 0 , 0}$ \\
\hline Total & $\mathbf{1 0 2 8}$ & $\mathbf{1 0 0 , 0}$ & \\
\hline
\end{tabular}

Source: Authors' analysis

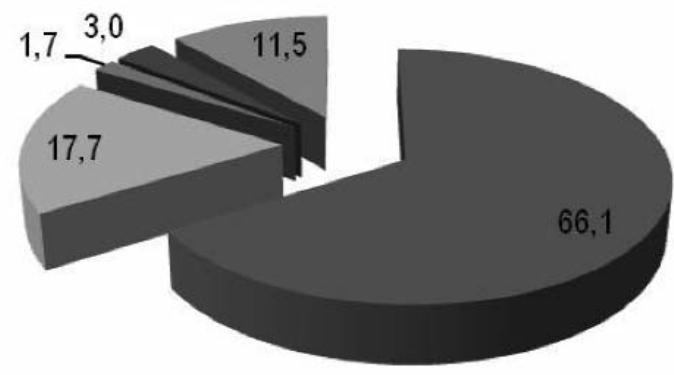

Source: Authors' analysis

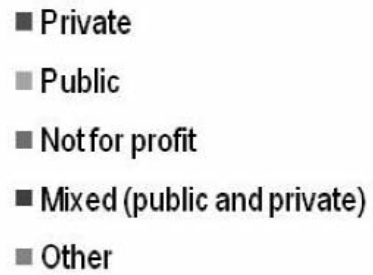

ather

Figure 1. Sector distribution of the sample 
between those organizations that do not have and those that have formal appraisal systems in relations to the level of organizational performances. Authors used two variables. First, the existence of the formal appraisal systems for managers (as a groping variable, dichotomous 0-no, 1-yes) and second the level of organizational performances measured by profitability, productivity, market share, rate of innovation, environmental performances (as a tested variable, given in form of Likert scale from 1-poor to 5-superior).

\section{RESULTS OF THE ANALYSIS}

First part of the analysis obtained the exploration of the percentage of the companies which use formal evaluation systems for managers. Figure 2 presents data on the existence of the formal appraisal systems for managers' performances in the countries of the Central and Eastern Europe.

According data from figure 2 , in the countries of the CEE in the field of performance evaluation of managers there is a general trend of the usage of the formal evaluation methods. The majority of the organizations form the CEE countries use these systems. Organizations from the Czech Republic and Slovakia have the largest percentage in this practice - over $75 \%$ of organizations that participated in the survey use formal systems of manager's appraisal). In addition, in Estonia, Hungary and Slovenia there is a similar situation, since more than $60 \%$ of organizations use formal appraisal systems. This may be the logical step if we consider the presented theoretically alleging that inadequate performance management can lead to an increase in adverse effects on the business process, which in the case of an international task boils down to the expatriate failure and the failure of the international operations. Also, since performance management is very closely linked to the contemporary models of rewarding employees, primarily based on earnings based on performances (pay for performance), measurement and evaluation of performances is the first step in determining the variable pay or bonuses, premiums and similar short-term and longterm incentives and benefits, which for managerial personnel, especially executive managers, amounted to over $80 \%$ of total compensation (Berber, 2012).

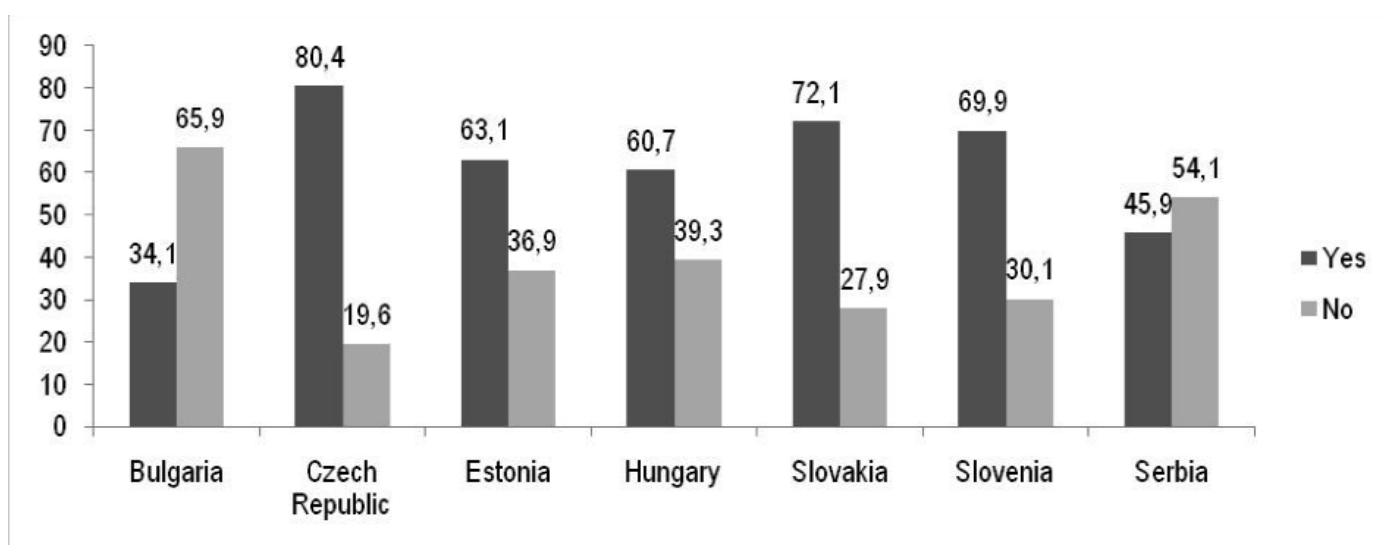

Source: Authors' analysis

Figure 2. Percentage of the formal performance evaluation systems for managers in the CEE region 
Beside these positive trends, two countries perform different than the rest of the CEE region. Namely, organizations from Serbia and Bulgaria have more companies which do not use formal appraisal systems in managers' performance measurement. For Bulgaria the percentage of companies that use formal systems is only 34.1 of organizations. In case of the Republic of Serbia it should be noted that organizations that operate in local conditions do not use formal methods of assessment in over than $54 \%$ of organizations. This trend is certainly not in the line with trends in Europe, but on the other hand, many developed countries such as Russia, Sweden and Lithuania have also a small percentage of organizations that use formal methods of performance measurement. This may be connected to the fact that the formal methods of measuring performances are sometimes expensive and require a lot of time, and on the other hand, under-trained HR managers do not even know how to implement them properly.

Table 3 below showed the percentages of the usage of certain actors who are responsible for providing inputs for the performance appraisal of managers. As it is evident, most of the organizations (over 90 $\%$ ) use immediate supervisor as a person who is responsible for the performance assessment of managers, which is consistent with the theoretical claims. The other actor, according table 3 , in this process is the supervisors' supervisor (about 56\%). The third reviewer is an employee (41\%) in terms of self-evaluation. Customers, peers and subordinates are used to a much lesser degree, $15.1 \%, 17.1 \%$ and $18.1 \%$ of organizations, respectively. What is also very noticeable is the large variation in terms of certain actors in the evaluation of performance. Only in the case of a direct supervisor there is convergence trend, in terms that all countries (organizations) in a similar percentage use this method, while the percentage of other stakeholders differs in a wide range. For example, employee self evaluation ranges from $14.6 \%$ of organizations in the Czech Republic to even $69.4 \%$ in Estonia. The usage of supervisor' superior vary from $17 \%$ in the Czech Republic to $81.8 \%$ in Serbia, and the like. In the category of colleagues, subordinates and customers there is less significant variation. Only organizations in Estonia use these reviewers in greater percentage $(53 \%$ for subordinates, $38.7 \%$ for peers and $25 \%$ for customers). On the other hand, organizations from the Czech Republic use these three methods less than the average $(7.3 \%$ of organizations use them).

In the case of Serbia, there are also some deviations from the CEE average, with the approximate percentage when it comes to immediate supervisors $\quad(83.3 \%$ of

Table 3. Percentage of the usage of different reviewers in managers' appraisal process

\begin{tabular}{|l|c|c|c|c|c|c|}
\hline & $\begin{array}{c}\text { Immediate } \\
\text { supervisor }\end{array}$ & $\begin{array}{c}\text { Supervisors } \\
\text { supervisor }\end{array}$ & Employee & Subordinates & Peers & Customers \\
\hline Bulgaria & 89,9 & 75,5 & 35,6 & 15,0 & 15,4 & 12,5 \\
\hline Czech Republic & 100,0 & 17,1 & 14,6 & 7,3 & 7,3 & 7,3 \\
\hline Estonia & 97,6 & 66,7 & 69,4 & 53,1 & 38,7 & 25,0 \\
\hline Hungary & 96,3 & 35,1 & 49,4 & 19,5 & 15,6 & 14,3 \\
\hline Slovakia & 90,6 & 55,7 & 45,3 & 15,3 & 17,3 & 15,3 \\
\hline Slovenia & 92,9 & 70,1 & 32,2 & 18,4 & 15,1 & 17,4 \\
\hline Serbia & $\mathbf{8 3 , 3}$ & $\mathbf{8 1 , 8}$ & $\mathbf{2 5 , 0}$ & $\mathbf{1 2 , 5}$ & $\mathbf{2 5 , 0}$ & $\mathbf{1 2 , 5}$ \\
\hline TOTAL & $\mathbf{9 3 , 1}$ & $\mathbf{5 5 , 8}$ & $\mathbf{4 1 , 2}$ & $\mathbf{1 8 , 6}$ & $\mathbf{1 7 , 1}$ & $\mathbf{1 5 , 1}$ \\
\hline
\end{tabular}

Source: Authors' analysis 
organizations in comparison to the $\mathrm{CEE}$ average of $93.1 \%$ ). However, the Serbian organizations use self-evaluation (only $25 \%$ of organizations in comparison with the CEE average of $41.2 \%$ ) while supervisor's superior is used more frequently $(81.8 \%)$ than the average in Central and Eastern Europe.

At the end of the research analysis authors explored whether there are differences in organizational performances between organizations in relation to the usage of the formal appraisal systems for managers. Table 4 presents mean values of organizational performances in relation to the usage of FAS for managers.

In general, from table 4 it is evident that organizations that use FAS have higher rate of all performance measures observed in the research and analysis. But, for deeper analysis it was also important to investigate whether these differences were statistically significant. Table 5 presented the t-test of independent samples as a method for exploring differences among groups.

T-test for independent samples was used to analyze the differences between organizations with and without formal appraisal systems for mangers' performance measurement in relations with the level of organizational performances. There was found a significant difference in case of service quality between organizations that use formal systems $(\mathrm{M}=3.98, \mathrm{SD}=0.654)$ and those that do not use such systems $(\mathrm{M}=3.81$, $\mathrm{SD}=0.718), \mathrm{t}(837)=3.583, \mathrm{p}<(0.000)$ twotailed. Significant statistical differences were found for each other performance measure. Namely, in case of productivity, organizations that use FAS $(\mathrm{M}=3.66$, $\mathrm{SD}=0.805)$ and those that do not $(\mathrm{M}=3.49$, $\mathrm{SD}=0.750$ ), have higher rate of productivity $\mathrm{t}(791)=2.780, \quad \mathrm{p}<(0.004)$ two tailed. A significant difference were also found in case of: profitability between organizations that use formal systems $(\mathrm{M}=3.47, \mathrm{SD}=0.919)$ and those that do not use such systems $(\mathrm{M}=3.17$, $\mathrm{SD}=0.858), \mathrm{t}(773)=4.680, \mathrm{p}<(0.000)$ twotailed, innovation rate between organizations that use formal systems $(\mathrm{M}=3.37, \mathrm{SD}=0.949)$ and those that do not use such systems $(\mathrm{M}=3.20, \quad \mathrm{SD}=1.003), \quad \mathrm{t}(783)=2.335$, $\mathrm{p}<(0.020)$ two-tailed, and environmental performances, between organizations that use formal systems $(\mathrm{M}=3.63, \mathrm{SD}=0.942)$ and those that do not use such systems $(\mathrm{M}=3.24$, $\mathrm{SD}=0.987), \mathrm{t}(745)=5.470, \mathrm{p}<(0.000)$ twotailed.

Table 4. Descriptive statistics for the usage of formal appraisal systems for managers and the level of organizational performances

\begin{tabular}{|l|l|r|r|}
\hline \multirow{2}{*}{ Rating of service quality } & $\begin{array}{l}\text { Formal appraisal system } \\
\text { for management }\end{array}$ & Mean & \multicolumn{1}{c|}{$\begin{array}{c}\text { Std. } \\
\text { Deviation }\end{array}$} \\
\hline \multirow{2}{*}{ Rating of level of productivity } & No & 3,81 &, 718 \\
\cline { 2 - 4 } & Yes & $\mathbf{3 , 9 8}$ &, 654 \\
\hline \multirow{2}{*}{ Rating of profitability } & No & 3,49 &, 750 \\
\cline { 2 - 4 } & Yes & $\mathbf{3 , 6 6}$ &, 805 \\
\hline \multirow{2}{*}{ Rating of rate of innovation } & No & 3,17 &, 858 \\
\cline { 2 - 4 } & Yes & $\mathbf{3 , 4 7}$ &, 919 \\
\hline \multirow{2}{*}{ Rating of environmental matters } & No & 3,20 & 1,003 \\
\cline { 2 - 4 } & Yes & $\mathbf{3 , 3 7}$ &, 949 \\
\cline { 2 - 4 } & No & 3,24 &, 987 \\
\cline { 2 - 4 } & Yes & $\mathbf{3 , 6 3}$ &, 942 \\
\hline
\end{tabular}

Source: Authors' analysis 
Table 5. Independent $T$-test for the organizational performances

\begin{tabular}{|c|c|c|c|c|c|c|c|}
\hline & \multicolumn{2}{|c|}{$\begin{array}{c}\text { Levene's Test for } \\
\text { Equality of } \\
\text { Variances } \\
\end{array}$} & \multicolumn{5}{|c|}{ t-test for Equality of Means } \\
\hline & \multirow[t]{2}{*}{$\mathrm{F}$} & \multirow[t]{2}{*}{ Sig. } & \multirow[t]{2}{*}{$\mathrm{t}$} & \multirow[t]{2}{*}{$\mathrm{df}$} & \multirow[t]{2}{*}{$\begin{array}{l}\text { Sig. } \\
(2- \\
\text { tailed })\end{array}$} & \multicolumn{2}{|c|}{$\begin{array}{l}95 \% \text { Confidence } \\
\text { Interval of the } \\
\text { Difference }\end{array}$} \\
\hline & & & & & & Lower & Upper \\
\hline \multirow[t]{2}{*}{ Rating of service quality } & 21,948 & ,000 & $-3,583$ & 837 &, 000 &,- 265 &,- 078 \\
\hline & & & $-3,521$ & 685,127 & ,000 &,- 267 &,- 076 \\
\hline \multirow[t]{2}{*}{ Rating of level of productivity } & ,906 & ,341 & $-2,870$ & 791 &, 004 &,- 273 &,- 051 \\
\hline & & & $-2,905$ & 733,298 &, 004 &,- 271 &,- 053 \\
\hline \multirow[t]{2}{*}{ Rating of profitability } & 8,709 & ,003 & $-4,680$ & 773 &, 000 &,- 433 &,- 177 \\
\hline & & & $-4,733$ & 722,819 &, 000 &,- 431 &,- 178 \\
\hline \multirow[t]{2}{*}{ Rating of rate of innovation } &, 104 & ,747 & $-2,335$ & 783 &, 020 &,- 303 &,- 026 \\
\hline & & & $-2,313$ & 668,349 &, 021 &,- 304 &,- 025 \\
\hline \multirow{2}{*}{$\begin{array}{l}\text { Rating of environmental } \\
\text { matters }\end{array}$} & ,219 & ,640 & $-5,470$ & 745 &, 000 &,- 531 &,- 250 \\
\hline & & & $-5,426$ & 643,694 &, 000 &,- 532 &,- 249 \\
\hline
\end{tabular}

Source: Authors' analysis

\section{CONCLUSION}

The impact of HRM policies and practices on firm performance is an important topic in the fields of human resource management, industrial relations, and industrial and organizational psychology (Huselid, 1995). Among many HRM activities, performance management is seen as one of the most complex and important for the successful of an organization, especially if the global environment is in the question.

Performance management in IHRM represents a designed and implemented intervention by the MNCs with the goal of the management of the performances of the global workforce (individual, team and organizational performances) so that those performances can contribute to the achievement of the global strategic objectives and results of MNCs. Also, PM in IHRM refers to the specific aim, the management of the expatriate performances.

In this paper authors explored the area of performance management form the aspect of IHRM and investigated trends in the PM practices across the CEE region. The main conclusions that are derived from the analysis were:

- Organizations from the CEE region generally use formal appraisal systems for mangers' performance measurement in great extent. $60 \%$ of all organizations use FAS, while $40 \%$ do not have these systems in use. Formal systems are important because they are seen as the preferable means to appraise, develop and effectively utilize employees' knowledge and capabilities (Moulik \& Mazumdar, 2012).

- Organizations from the CEE region usually use a direct supervisor for the evaluation process. Beside them, supervisors' supervisor and self evaluation are also used in great advance. The usage of peers, subordinates and customers is lower in the process of performance measurement of managers' performances.

- Statistically significant differences were found between organizations that use and those that do not use formal appraisal systems for managers in respect to the level of organizational performances. In case of all observed performance indicators profitability, productivity, rate of innovation, 
environmental performances and service quality authors found that if organizations use formal systems of appraisal for their managers, the level of analyzed performances is higher.

\section{References}

Beh, L., \& Loo, L. (2013). Human resource management best practices and firm performance: A universalistic perspective approach. Serbian Journal of Management, 8(2): 155-167.
Berber, N. (2012). Strategic Management of the Compensation System for Managers in Conditions of the Economic Crisis. XVII International Scientific Conference Strategic Management and Decision Support Systems in Strategic Management SM 2012. Subotica: Faculty of Economics. (In Serbian) Berber, N., Pasula, M., Radosevic, M., Ikonov, D., \& Kocic Vugdelija, V. (2012). Internal Audit of Compensations and Benefits: Tasks and Risks in Production Systems. Inzenerine ekonomika Engineering Economics, 23(4): 414-424.

\title{
МЕНАЏМЕНТ ПЕРФОРМАНСИ У МЕБУНАРОДОНОМ МЕНАЏМЕНТУ ЉУДСКИХ РЕСУРСА: РЕЗУЛТАТИ ИСТРАЖИВАЊА У ЦЕНТРАЛНО-ИСТОЧНОЈ ЕВРОПИ
}

\author{
Агнеш Славић, Немања Бербер, Бојан Лековић
}

\begin{abstract}
Извод
Менаџмент перформанси (ПМ) је веома значајан процес у овиру менаџмента људских ресурса („ХРМ“). Подразмева процену тренутних или претходних резултата или перформанси запослених, тимова или целокупне организације. Овај процес је основа за многе друге ХРМ активности као што су утврђивање потребе за обуком, новим запошљавањем, развој каријере, награђивање и др. У богатој литератури у овој области истиче се да је ПМ комплексан процес, нарочито уколико се у контексту истраживања посматра глобално тржиште и пословање. Овај рад истражује перформанс менаџмент са спекта међународног менаџмента људских ресурса (ИХРМ). Основни циљ овог истраживања био је истраживање перформанс менаџмента у контексту ИХРМ-а и односа између постојања формалних система процене (ФАС) и организационих перформанси. Истраживање је спроведено кроз теоријску и емпиријску анализу која је базирана на подацима из „CRANET“ пројекта. Методологија која је коришћена у раду обухватила је технике као што су дескриптивна статистика и индепендент т-тест, применом програма СПСС. Аутори су истражили податке из организација из седам земаља региона централно-источне Европе.
\end{abstract}

Кључне речи: Менаџмент перформанси, међународни менаџмент људских ресурса, формални системи процене, менаџери, Централна и Источна Европа 
Brewster, C. (1991). The Management of Expatriates. London: Kogan Page.

Brewster, C., \& Scullion, H. (1997). A review and agenda for expatriate HRM. Human Resource Management Journal, 7(3): 32-41.

Brewster, C., Sparrow, P., \& Vernon, G. (2007). International Human Resource Management (2. izd.). London: Chartered Institute of Personnel and Development.

Briscoe, D.R., Schuler, R.S., \& Claus, L. (2009). International Human Resource Management - Policies and practice for multinational enterprises. London and New York: Routledge.

Caligiuri, P.M. (2006). Performance measurement in a cross-cultural context: Evaluating the success of global assignments. U: W. Bennett, C. Launce, i J. Woehr (Eds), Performance Management: Current Perspectives and Future Challenges, 227-244. Mahwah, NJ: Lawrence Erlbaum Associates.

Cascio, W.F. (2006). Global performance management systems. pp. 176-196. In G.K. Stahl \& I. Bjorkman (Eds.), Handbook of Research in International Human Resource Management. Northhampton, MA: Edward Elgar Publishing.

Dowling, P.J., Festing, M., \& Engle, A.D. SR. (2008). International Human Resource Management - Managing people in a multinational context. London: Cengage Learning.

Engle, Sr, A.D., Dowling, P.J., \& Festing, M. (2008). State of origin: research in global performance management, a proposed research domain and emerging implications. European Journal of International Management, 2(2): 153-169.

Evans, P., Pucik, V., \& Björkman, I. (2011). Global performance management. pp. 346-390. In P. Evans, V. Pucik, \& I.
Björkman (Eds.), The global challenge: International human resource management (Vol. 2). New York, NY: McGraw-Hill.

Festing, M., \& Eidems, J. (2011). A process perspective on transnational HRM systems-A dynamic capability-based analysis. Human Resource Management Review, 21(3): 162-173.

Festing, M., Knappert, L., Dowling, P.J., \& Engle, A.D. (2012). Global Performance Management in MNEs-Conceptualization and Profiles of Country-Specific Characteristics in China, Germany, and the United States. Thunderbird International Business Review, 54(6): 825-843.

Godiwalla, Y.H. (2012). Training and Development of the International US Executive. Journal of Modern Accounting and Auditing, 8(1): 32-39.

Gregersen, H.B., Hite, J.M., \& Black, J.S. (1996). Expatriate performance appraisal in US multinational firms. Journal of International Business Studies, 27(4): 711738.

Huselid, M.A. (1995). The impact of human resource management practices on turnover, productivity, and corporate financial performance. Academy of Management Journal, 38(3): 635-672.

Kaplan, R.S., \& Norton, D.P. (1996). The Balanced Scorecard: Translating Strategy into Action. Boston: Harvard Business School Press. N.P.

Kennerley, M. \& Neely, A. (2002). A framework of the factors affecting the evolution of performance measurement systems. International Journal of Operations \& Production Management, 22(11): 12221245.

Lardenoije, E.J.H., Van Raaij, E.M., \& Van Weele, A.J. (2005). Performance management models and purchasing: Relevance still lost. Researches in 
purchasing and supply management, Accuracy - a Case Study for Romanian Proceedings of the 14th IPSERA Macroeconomic Forecast. Serbian Journal of Conference, Archamps, France, 687-697. Management, 8(1): 53-65.

Lee, H.W., \& Liu, C.H. (2006). Determinants of the Adjustment of Expatriate Managers to Foreign Countries: An Empirical Study. International Journal of Management, 23(2): 302-311.

McNamara, T.K., Parry, E., Lee, J., \& Pitt-Catsouphes, M. (2012). The effect of training on organizational performance: differences by age composition and cultural context. The International Journal of Human Resource Management, 23(6): 1226-1244.

Moulik, S.R., \& Mazumdar, S. (2012). Exploring the Relationship Between Perceived Uses of Appraisals And Performance Appraisal Satisfaction in The Indian It Sector: An Empirical Study. International Journal of Business and Social Research, 2(5): 63-76.

Mura, L. (2012). Performance of human resource management in an internationally operating company. Serbian Journal of Management, 7(1): 115-129.

Neely, A.D., Gregory, M., \& Plats, K. (1995). Performance measurement system design: A literature review and research agenda. International Journal of Operations \& Production Management, 15(4): 80-116.

Papalexandris, N., \& Panayotopoulou, L. (2004). Exploring the mutual interaction of societal culture and human resource management practices: Evidence from 19 countries. Employee Relations, 26(5): 495509.

Poor, J., Nikolić, M., Slavić, A., \& Štangl - Šušnjar, G. (2012). HRM under Changes at Foreign Subsidiaries in Serbia in Line With a Central and Eastern European Survey. Strategic Management, 17(1): 42-52.

Simonescu - Bratu, M. (2013). Improvements in Assessing the Forecast Anderson, N. (2012). Measuring HRM and organizational performance: concepts, issues, and framework. Management Decision, 50(4): 651-667.

Štangl Šušnjar, G., \& Slavić, A. (2012). Changes in the human resource compensation systems of European companies: Based on the CRANET research result analysis. Strategic Management, 17(4): 32-40.

Štangl Šušnjar, G., Slavić, A., \& Berber, N. (2013). The Analysis of Human Resource Outsourcing in Central and Eastern Europe. Metalurgia International, 18(11): 57-61.

Štangl-Šušnjar, G. \& Zimanji, V. (2005). Human Resource Management (Menadžment ljudskih resursa). Subotica: Faculty of Economics.

Susomrith, P., \& Brown, A. (2013). Motivations for HR outsourcing in Australia. The International Journal of Human Resource Management, 24(4): 704-720.

Vance, C. M. (2006). Strategic upstream and downstream considerations for effective global performance management. International Journal of Cross Cultural Management, 6(1): 37-56.

Woods, P.R., Barker, M.C., \& Troth, A.C. (2012). Cross-cultural management performance elements in the expatriate context. International Journal of Business Research, 12(3): 95-108. 